\title{
New Osteological Data on Malaria in Sardinia from Antiquity to the Modern Era
}

\author{
Eugenia Tognotti1,2, Andrea Montella1,2, Peter J. Brown ${ }^{3}$, Pasquale Bandiera1,2 \\ ${ }^{1}$ Department of Biomedical Sciences, University of Sassari, Sassari, Italy \\ ${ }^{2}$ Center for Anthropological, Paleopathological and Historical Studies of the Sardinian and Mediterranean Populations, \\ Department of Biomedical Sciences, University of Sassari, Sassari, Italy \\ ${ }^{3}$ Department of Anthropology, Emory University, Atlanta, GA, USA \\ Email: tognotti@uniss.it
}

How to cite this paper: Tognotti, E., Montella, A., Brown, P.J. and Bandiera, P. (2017) New Osteological Data on Malaria in Sardinia from Antiquity to the Modern Era. Advances in Infectious Diseases, 7, 37-44. https://doi.org/10.4236/aid.2017.72005

Received: May 15, 2017

Accepted: June 11, 2017

Published: June 14, 2017

Copyright (c) 2017 by authors and Scientific Research Publishing Inc. This work is licensed under the Creative Commons Attribution International License (CC BY 4.0).

http://creativecommons.org/licenses/by/4.0/ cc) (†) Open Access

\begin{abstract}
Malaria has been an important disease throughout the history, particularly in the Mediterranean. The island of Sardinia (Italy) was characterized by severe endemic malaria from antiquity until its eradication in 1950. It provides an exceptional and unique site to examine the history of the disease and its effects on human biology and ecology. Endemic malaria can cause chronic hemolytic anemias that may result in osteological signatures. This paper examines these markers, Porotic Hyperostosis (PH) and Cribra Orbitalia (CO), which are identified from skeletons uncovered in archaeological excavations in Northern Sardinia. Previous hypotheses based on historical references and genetic data suggest that the disease was absent on the island in prehistory and was imported, probably by slaves, during the Carthaginian period (6th to 3rd century BC). This article reports on the paleontological analysis of 283 skeletons excavated from seven archeological sites dating from $4700 \mathrm{BP}$ to 1582 AD. Osteological remains were examined for markers $\mathrm{CO}$ and $\mathrm{PH}$ as a proxy variable for malaria. The findings support previous hypotheses about history of malaria over time.
\end{abstract}

\section{Keywords}

Malaria, Porotic Hyperostosis, Sardinia, Paleopathology

\section{Introduction}

Within Mediterranean Europe, Sardinia had the misfortune of being both malaria ridden and characterized by high mortality rates due to the co-existence of Plasmodium falciparum and Plasmodium vivax strains. This was temperate climate malaria, with an annual epidemic peak in summer because of $P$. vivax. In 
Sardinia, the disease was a critical historical factor that shaped population genetics, economy, and culture [1] [2]. The island is an exceptional and unique location for examining the history of malaria in a particular ecological context because of the existence of ancient texts from the 1st century BC until the postWWII eradication of the disease. This documentary evidence can now be supplemented with bio archaeological data.

The current consensus about the history of malaria in Sardinia, particularly the question of when and how the disease became endemic, is as follows [3]. The indigenous Sardinian population built many impressive megalithic structures called Nuraghe erected between the Bronze and Iron ages (Nuragic Period). During the Pre-Nuragic and Nuragic periods, malaria was very rare or absent. According to entomological studies, the primary malaria vector, Anopheles labranchiae, was indigenous to the island and pre-existed human habitation [4] [5]. Malaria was probably imported in 6th century BC during Carthaginian contact, when the invaders brought Berbers slaves from North Africa to cultivate parts of the Campidano, a fertile plain near the middle and south of the island characterized by multiple swamps. These ecological and epidemiological conditions of concentrated slave labor and conditions favorable for mosquitoes allowed the diffusion of the disease to native groups.

During the Roman domination (238 BC-456 AD) numerous authors maligned Sardinia as an "insalubrious island." Their descriptions of an endemic disease seem consistent with febrile symptoms of $P$. vivax ("Benign Tertian") or $P$. malariae ("Quartan") [2]. In the early first century, Strabo, the famous geographer of antiquity (60 $\mathrm{BC}-24 \mathrm{AD})$, provided a type of malaria map showing that the disease was probably confined to coastal and inland plains. In his classical treatise Geography, Strabo also observed that the island was unhealthy in summer and limited to the more fertile plains. Also in the early first century Titus Livio (59 BC-17 AD) in his book $A b$ Urbe Condita [6] states that during the Second Punic War, governor Quintus Mucius Scaevola became ill in Sardinia with a disease that was long but not fatal; it was probably the "Tertian" by $P$. vivax, active all the year [2].

The current consensus is that the prevalence $P$. falciparum increased significantly, between the 8th and 13th centuries, possibly coinciding the climate shift called the "Medieval Warm Period" [7]. The presence of malaria, locally called Intemperie [8] was reported by many travelers, local observers, physicians, and other scholars during the 15th through 17 th centuries.

For the first two decades of the 20th century, the average annual number of deaths attributed to malaria in Sardinia oscillated between 2000 and 2200 [9]. This corresponds to a mortality rate of over 250 per 100,000; the highest malaria mortality rate in contemporary Africa is 75 per 100,000 [10]. Malaria mortality on the island decreased significantly after the unification of Italy and a series of national laws begun in 1900 assuring the distribution of quinine through a subsidized state monopoly [6] [11]. In the three years following the initiation of these laws, the malaria mortality rate in Sardinia decreased from 250 per 100,000 
to 154 per 100,000. Further anti-malaria efforts lowered the island's malaria death rate to 55 in 1930 and 25 in 1940. Malaria was completely eliminated from Sardinia in 1950 after a massive DDT campaign directed by the Rockefeller International Health Foundation [2] [11] [12] [13].

\section{Methods}

All human bones discovered by archaeologists in the seven sites were excavated and transported to the paleoanthropology laboratory at University of Sassari using standard procedures [14] [15]. All osteological materials were well preserved and previous research demonstrated that they had maintained their morphological and molecular structures [16] [17]. Complete skeletal biological data was collected for each skeleton, as conditions allowed, for variable including age, sex, stature and indications of general health [14] [16] [17] [18] [19] [20]. Standard paleopathological techniques for description and analysis of lesions or other pathological markers were utilized with special attention to $\mathrm{PH}$ and $\mathrm{CO}$ in crania [14] [18] [19] [20] [21] [22]. Porotic Hyperostosis (PH) is characterized by increased thickness of the cranial bone (hyperostosis) together with a porous or spongy appearance of the outside covering of the cranium. When the porous character is found in the thin osteological anterior ceiling of the orbital cavity, it is labelled Cribra Orbitalia (CO). As such, CO is marker of a lighter form of anemia while $\mathrm{CO}$ associated with $\mathrm{PH}$ is characteristic of a more severe form of anemia [23]. An image of CO from the current sample is seen in Figure 1.

The archaeological excavations described here represent a long period of time, from $4700 \mathrm{BP}$ to $1582 \mathrm{AD}$ that can be divided into five periods-1) Pre-Nuragic ( 4700 BP); 2) Nuragic ( 2700 BP to $238 \mathrm{AD})$; 3) Roman occupation (238 BC-456 AD); 4) Medieval (5th-15th centuries); and 5) the Bubonic Plague in the city of Alghero (1582-1583). The archaeological sites, radiocarbon dates, the number of individuals by sex and average age, number of infants and total number of skeletons are found in Table 1.

The specific archaeological sites were: 1) Pre-Nuragic-Ossi, "S'adde 'e Asile",

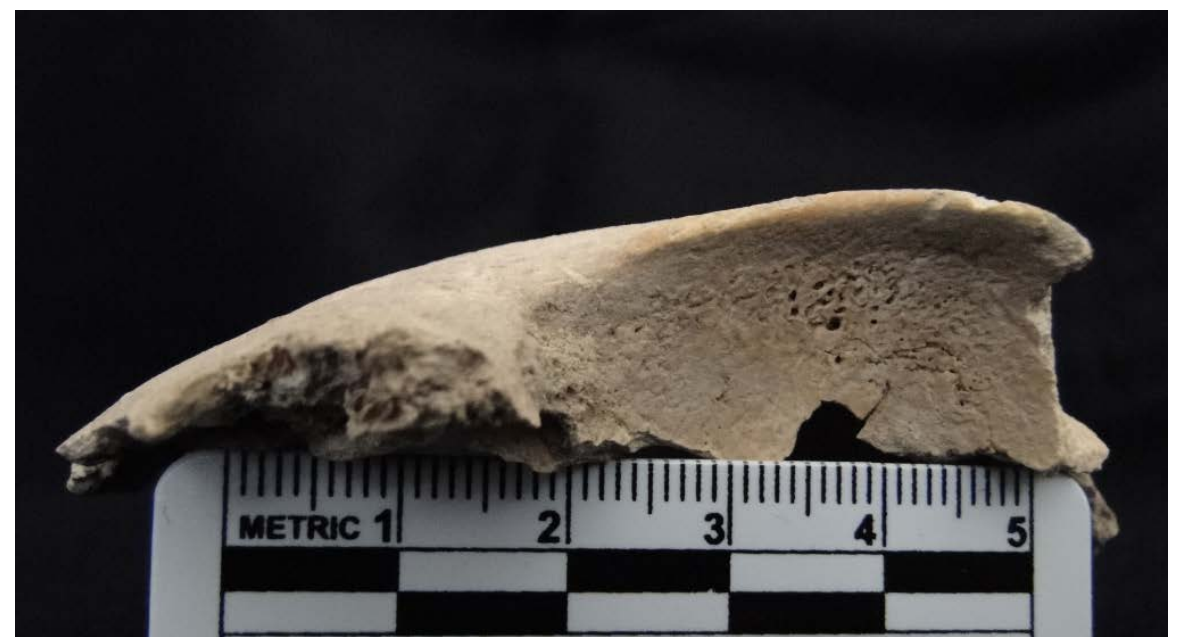

Figure 1. Cribra orbitalia in left orbit, San Nicola (Sassari) [Medieval]. 
Table 1. Characteristics of sites and skeletal samples for prehistoric and historic periods.

\begin{tabular}{|c|c|c|c|c|c|c|c|c|}
\hline Period & Sites & $\mathrm{C}^{14}$ Dates & Sub-Adult & $\# \mathrm{M}$ & Age-M & $\# \mathrm{~F}$ & Age-F & Total Individuals \\
\hline Pre-Nuragic (Neolithic) & 2 & 4712 - 3594 BP & 60 & 41 & 26.7 & 53 & 28.7 & 94 \\
\hline Nuragic (Bronze) & 1 & $2750-2561 \mathrm{BP}$ & 10 & 29 & 30 & 30 & 50 & 59 \\
\hline Roman & 1 & $1^{\text {st }} 3^{\text {rd }}$ Cen. AD & 2 & 21 & 31.5 & 16 & 29.6 & 37 \\
\hline Medieval & 2 & $13^{\text {th }}-15^{\text {th }}$ Cen. AD & 4 & 32 & $30-39$ & 31 & $30-39$ & 63 \\
\hline Plague & 1 & $1582 \mathrm{AD}$ & 0 & 12 & $20-29$ & 18 & $20-29$ & 30 \\
\hline
\end{tabular}

Sassari Province; Ossi, "Noeddale” Sassari Province; 2) Nuragic-Ittiri "Sa Figu”, Sassari Province; 3) Roman-Alghero, "Monte Carru”, Sassari Province; 3) Medieval-Sassari, "San Nicola, cimitero esterno", Sassari Province; Alghero-"Lo Quarter”, Sassari Province; 4) Alghero Plague cemetery (Modern era)-“San Michele", Sassari Province.

\section{Discussion}

Many authors agree that there is a relationship between chronic anemia and the paleopathological signs of Porotic Hyperostosis and Cribra Orbitalia [21] [22] [23]. This relationship has been discussed within bioarchaeology for a long time, beginning with Angel [24] who argued that $\mathrm{CO}$ and $\mathrm{PH}$ were indirect indications of malaria in Greece and the eastern Mediterranean. Angel's hypothesis was partly based on writings from the classic age; as we do here. On the other hand, paleopathologists of ancient Native America, specifically the Southwest, have traditionally considered $\mathrm{PH}$ a marker of anemia caused by nutritional stress and iron deficiency [23] [25] [26]. The climate of the Southwestern North America does not support malaria transmission; therefore Angel's hypothesis does not fit that context. The idea of a binary nutrition $v s$. malaria is untenable.

However, Walker and colleagues have recently argued that hemolytic anemia can be acquired by numerous factors besides iron deficiency [27]. Instead, they refer to anemias caused by chronic parasitic infections, like malaria, as well as congenital conditions of Thalassemia, Sickle-Cell trait-all of which are well known to be balanced polymorphisms that are adaptive in the context of severe malaria and have been characteristic of Mediterranean populations [28] [29]. The close relationship between the distribution of such abnormal genes and malaria has been demonstrated many times with data from Sardinia ([30] [31] [32] [33] and other localities [24] [34]-[39]. Paleopathologists of the Mediterranean basin consider skeletal remains with $\mathrm{PH}$ to be a sign of chronic hemolytic anemia caused by malaria, thalassemia, and sickle cell disease.

Based on excavations in central Italy (Umbria), Soren [40] has described ecological and archaeological contexts which are best interpreted as evidence of malaria epidemics. Soren's case seems unique in that the cemetery at Lugnano consisted exclusively of infants. Furthermore, Sallares and Gomzi [41] have reported the extraction of DNA from Plasmodium falciparum from infant burials in Italy during the Roman period. This evidence suggests that it is reasonable to 
assume that in the paleopathological context of Sardinia in the past, $\mathrm{PH}$ and $\mathrm{CO}$ were primarily the expression of chronic anemia as a consequence of malaria. This assumption is also based on numerous historical documents regarding Sardinia from various historical periods. Future analysis of the stature of the prehistoric populations (especially from the Nuragic age) - an ongoing effort of the current research-will also provide evidence for hypothesis that $\mathrm{PH}$ and $\mathrm{CO}$ in Sardinia is best considered evidence of malaria.

\subsection{Findings}

Table 2 presents findings on the frequency of $\mathrm{CO}$ for the five prehistoric and historic periods. In general, CO is very low or absent in earliest archaeological sites as hypothesized [3]. In laboratory analysis, the single diagnosis of CO in a Pre-Nuragic cranium was equivocal. The absence of CO during the Roman period may be related to the fact that skeletons in this sample are from Northern Sardinia sites, where there were far fewer Roman latifundia than in the Campidano.

The very high prevalence of CO in the plague cemetery of 1582 is interesting and deserves further historical study. It will also be important in the future to combine these results with some earlier paleopathological descriptions from previously excavated sites which, unfortunately, do not contain sufficient information for precise comparison [23] [25] [26]. These earlier reports suggest that there were different histories of malaria in Sardinia for different areas of the island.

\subsection{Limitations}

As in all research using paleopathological methods, this study has significant limitations. These include: the opportunistic method for finding skeletons results in small numbers and non-random sampling that make statistical comparisons inappropriate; diagnosis of $\mathrm{PH}$ and $\mathrm{CO}$ is observational and subjective; the materials are all from North Sardinia and cannot be representative of the entire island; the analyzed skeletons did not include many infants and children, a subpopulation more sensitive to malaria and anemia.

Table 2. Cribra orbitaria or cribra crania for prehistoric and historic periods.

\begin{tabular}{cccc}
\hline Period & Total Individuals & $\begin{array}{c}\text { Cribra Orbitaria or } \\
\text { Cribra Crania }\end{array}$ & $\begin{array}{c}\text { Percent } \\
\text { Cribra }\end{array}$ \\
\hline $\begin{array}{c}\text { Pre-Nuragic } \\
\text { (Neolithic) }\end{array}$ & 94 & 1 & 1 \\
$\begin{array}{c}\text { Nuragic } \\
\text { (Bronze) }\end{array}$ & 59 & 0 & 0 \\
Roman & 37 & 0 & 0 \\
Medieval & 39 & 6 & 15 \\
Plague & 30 & 15 & 50 \\
\hline
\end{tabular}




\section{Conclusion}

Fortunately, Sardinia is a unique case of a malaria endemic regional that can be studied by both historical documents and bio archaeological methods. The historical texts are ancient, dating to the Roman period, and are supported by osteological evidence as described here. Reconstructing the long history of malaria in Sardinia is an important part of understanding the long-term influence of the disease and its relationship with ecological change.

\section{Acknowledgements}

We would like to thank Valentina Giuffra (University of Pisa) and Marco Milanese (University of Sassari) for the data of Alghero. The co-author Peter J. Brown wants to thank the US-Italy Fulbright Commission for his support.

\section{References}

[1] Brown, P.J. (1981) Cultural Adaptations to Endemic Malaria in Sardinia. Medical Anthropology, 5, 311-339.

[2] Tognotti, E. (2008) Per una Storia della Malaria in Italia: Il Caso della Sardegna. 2nd Edition, Milano: Franco Angeli.

[3] Brown, P.J. (1984) Malaria in Nuragic, Punic, and Roman Sardinia: Some Hypotheses. In: Balmouth, M.S., Ed., Studies in Sardinian Archeology, University of Michigan Press, Ann Arbor, 209-235.

[4] Aitken, T. (1953) Notes Anopheline Fauna of Sardinia. In: Logan, J., Ed., The Sardinian Project: An Experiment in the Eradication of an Indigenous Malarious Vector, Johns Hopkins University Press, Baltimore.

[5] Trapido, H. (1951) Factors Influencing the Search for Anopheline Larvae in Sardinia. Journal of National Malaria Society, 10, 318-326.

[6] Hamilton, H.C.T. (1903) The Geography of Strabo. George Bell \& Sons, London.

[7] Ortolani, F. and Pagliucca, S. (2003) Cyclical Climatic-Environmental Changes in the Mediterranean Area (2500 BP-Present Day). PAGES, 11, 15.

[8] Farina, A. (1651) Medicinale Patrocinium ad Tyrones Sardianiae Medicos. Apud Jacobum Sarzina, Venice.

[9] ISTAT (1955) Cause delle Morte. Rome.

[10] World Life Expectancy. Malaria Mortality (per 100,000). World Health Expectancy 2017. http://www.worldlifeexpectancy.com/cause-of-death/malaria/by-country/

[11] Tognotti, E. (2009) Program to Eradicate Malaria in Sardinia, 1946-1950. Emerging Infectious Disease, 15, 1460-1466. https://doi.org/10.3201/eid1509.081317

[12] Logan, J. (1953) The Sardinian Project: An Experiment in the Eradication of an Indigenous Malarious Vector. Johns Hopkins University Press, Baltimore.

[13] Snowden, F. (2006) The Conquest of Malaria: Italy, 1900-1962. Yale University Press, New Haven.

[14] Bass, W.M. (1971) Human Osteology: A Laboratory and Field Manual of the Human Skeleton. Missouri Archaeological Society, Columbia, MO.

[15] Lavan, L. and Mulryan, M., Eds. (2013) Field Methods and Post-Excavation Techniques in Late Antique Archaeology. Leiden, Brill.

[16] Tedde, G., et al. (1995) Nuragic Bone Collagen Retains Its Molecular Structure. Italian Journal of Anatomy and Embryology, 100, 195-202. 
[17] Wojtowicz, A., et al. (1999) Persistence of Bone Collagen Cross-Links in Skeletons of the Nuraghi Population Living in Sardinia 1500-1200 B.C. Calcified Tissue International, 64, 370-373. https://doi.org/10.1007/PL00005816

[18] Buikstra, J.E. and Ubelaker, D.H. (1994) Standards for Data Collection from Human Skeletal Remains. Research Seminar Series 44, Arkansas Archaeological Survey, Fayetteville, AR.

[19] Canci, A. and Minozzi, S. (2015) Archeologia dei resti umani: dallo scavo al laboratorio. Carocci Editore, Roma.

[20] Martin, R. and Saller, K. (1959) Lahrbuch der anthropologie in systematische Darstlling. Fischer Verlang, Stuttgart.

[21] Ortner, D.J. and Putschar, W. (1985) Identification of Pathological Condition in Human Skeletal Remains. Smithsonian Institute Press, Washington DC.

[22] Ubelaker, D.H. (1989) Human Skeletal Remains. Taraxacum, Washington DC.

[23] Stuart-Macadam, P. (1987) Porotic Hyperostosis: New Evidence to Support the Anemia Theory. American Journal of Physical Anthropology, 74, 521-526. https://doi.org/10.1002/ajpa.1330740410

[24] Angel, J.L. (1966) Porotic Hyperostosis: Anemias, Malaria, and the Marshes of the Eastern Mediterranean. Science, 153, 760-763. https://doi.org/10.1126/science.153.3737.760

[25] Pinhasi, R. and Mays, S., Eds. (2008) Advances in Human Paleopathology. Wiley, Chichester.

[26] Waldron, T. (2009) Paleopathology. Cambridge University Press, Cambridge.

[27] Walker, P., et al. (2009) The Causes of Porotic Hyperostosis and Cribra Orbitalia: A Reappraisal of the Iron-Deficiency Anemia Hypothesis. American Journal of Physical Anthropology, 139, 109-125. https://doi.org/10.1002/ajpa.21031

[28] Haldane, J.B.S. (1949) Disease and Evolution. Ricerca Scientifica, 19, 68-76.

[29] Livingstone, F.B. (1958) Anthropological Implications of Sickle Cell Gene Distribution in West Africa. American Anthropologist, 60, 533-562. https://doi.org/10.1525/aa.1958.60.3.02a00110

[30] Siniscalco, M., Bernini, L., Latte, B. and Motulsky, A.G. (1961) Favism and Thalassnemia in Sardinia and Their Relationship to Malaria. Nature, 190, 1179-1180.

[31] Germana, F. and Ascenzi, A. (1980) Porotic Hyperostosis in Sardinia. Journal of Human Evolution, 9, 75-78. https://doi.org/10.1016/0047-2484(80)90045-7

[32] Sanna, E., et al. (1998) Micromapping the Distribution of G6Pd Deficiency in Sardinia with Data Collected from the 1950s to the 1980s. In: Greene, L. and Danubio, M.A., Eds., Adaptation to Malaria: The Interaction of Biology and Culture, CRC Press, New York.

[33] Calo, C.M., et al. (2008) Sardinian Population (Italy): A Genetic Review. International Journal of Modern Anthropology, 1, 1-121.

[34] Fraser, G.R., et al. (1964) Thalassemias, Abnormal Hemoglobins and Glucose-6Phosphate Dehydrogenase Deficiency in the Arta Area of Greece: Diagnostic and Genetic Aspects of Complete Village Studies. Annals of the New York Academy of Sciences, 119, 415-435. https://doi.org/10.1111/j.1749-6632.1965.tb54044.x

[35] Ascenzi, A. and Balistreri, P. (1977) Porotic Hyperostosis and the Problem of the Origins of Thalassemia in Italy. Journal of Human Evolution, 6, 595-604. https://doi.org/10.1016/S0047-2484(77)80132-2

[36] Borza, E.N. (1979) Some Observations on Malaria and the Ecology of Central Macedonia in Antiquity. American Journal of Ancient History, 4, 103-124. 
[37] Tayles, N. (1996) Anemia, Genetic Diseases and Malaria in Prehistoric Mainland Southeast Asia. American Journal of Physical Anthropology, 101, 11-27. https://doi.org/10.1002/(SICI)1096-8644(199609)101:1<11::AID-AJPA2>3.0.CO;2-G

[38] Gowland, R.L. and Western, A.G. (2012) Morbidity in the Marshes: Using Spatial Epidemiology to Investigate Skeletal Evidence for Malaria in Anglo-Saxon England (AD 410-1050). American Journal of Physical Anthropology, 147, 301-311. https://doi.org/10.1002/ajpa.21648

[39] Smith-Guzman, N.E. (2015) The Skeletal Manifestation of Malaria: An Epidemiological Approach Using Documented Skeletal Collections. American Journal of Physical Anthropology, 158, 624-635. https://doi.org/10.1002/ajpa.22819

[40] Soren, D. (2003) Can Archaeologists Excavate Evidence of Malaria? World Archaeology, 35, 193-209. https://doi.org/10.1080/0043824032000111371

[41] Sallares, R. and Gomzi, S. (2000) Biomolecular Archaeology of Malaria. Ancient Biomolecules, 3, 195-213.

Submit or recommend next manuscript to SCIRP and we will provide best service for you:

Accepting pre-submission inquiries through Email, Facebook, LinkedIn, Twitter, etc. A wide selection of journals (inclusive of 9 subjects, more than 200 journals)

Providing 24-hour high-quality service

User-friendly online submission system

Fair and swift peer-review system

Efficient typesetting and proofreading procedure

Display of the result of downloads and visits, as well as the number of cited articles

Maximum dissemination of your research work

Submit your manuscript at: http://papersubmission.scirp.org/

Or contact aid@scirp.org 